\title{
FORMATION OF FUTURE DOCTORS' PROFESSIONAL CULTURE
}

\author{
A. V. Ovsiannikova \\ Kharkiv National Medical University \\ 4 Nauky Avenue, Kharkiv, Ukraine, 61022 \\ anna.again66@gmail.com, http://orcid.org/0000-0001-8426-6313 \\ T. V. Lutaieva \\ V. N. Karazin Kharkiv National University \\ 4 Svobody Sq., Kharkiv, Ukraine, 61022 \\ t.lutaeva@gmail.com, http://orcid.org/0000-0002-5825-560X
}

\begin{abstract}
In the article it was analyzed the peculiarities of the formation of the professional culture of future doctors in the educational space of Ukrainian institutions of higher education. It was stated that the component of the professional culture of the doctor is a communicative culture, which involves the formation of foreign competence of future doctors in teaching the discipline "Foreign language (in professional direction)». The author focuses on the existence of tradition of intercultural interaction in the educational space of the medical school in Slobozhanshchyna during the imperial era. The article gives examples of the formation of skills of successful professional speech activity in foreign languages at the Imperial Kharkiv University. It has been determined that professionally directed medical foreign language is an integrated subject, which combines the coverage of grammar, vocabulary, spelling and punctuation in general with the classical foreign language, as well as the study of grammar, vocabulary and stylistics of a medical foreign language. It is noted that professionally directed medical foreign language is also closely connected with the subjects of medical and cultural orientation.

The structural components of the professional foreign language competence of the physician are determined, which include: axiological (motives, goals, values), cognitive (transformation of foreign language knowledge of different levels in the professional field of activity) and activity (skills, forms and methods of using foreign language knowledge in professional activity). It is noted that the activity component of the professional foreign language competence of the physician involves the implementation of the principles of personal and professional orientation, cooperation, multifunctionality, problem approach, as well as the introduction of problem-based teaching methods. It has been established that the introduction into the educational process of problem tasks causes the interpretation and updating of professional information in foreign language classes, critical thinking of medical students. Further research is required in the field of theoretical analysis of the teaching of the discipline "Foreign Language (in professional orientation)" as a means of introducing innovative teaching methods and technologies with the aim of forming the competence of future foreign doctors.
\end{abstract}

Key words: professional culture, doctor, professional foreign language competence, University, components of professional foreign language competence of a physician, student.

\section{Г. В. Овсяннікова}

Харківський національний медичний університет Проспект науки 4, Харків, Україна, 61022

Т. В. Лутаєва

Харківський національний університет імені В Н. Каразіна майдан Свободи 4, Харків, Україна, 61022

ФОРМУВАННЯ ПРОФЕСІЙНОї КУЛЬТУРИ МАЙБУТНІХ ЛІКАРІВ

У статті проаналізовано особливості формування професійної культури майбутніх лікарів у вітчизняному освітньому просторі закладів вищої освіти. Констатовано, що складовою професійної культури лікаря $€$ комунікативна культура, що передбачає формування іншомовної компетентності майбутніх лікарів при викладанні дисципліни «Іноземна мова (за професійним спрямуванням)». Автори акцентують увагу на існуванні традицій міжкультурної взаємодії в освітньому просторі вищої медичної школи на Слобожанщині за часів імперської доби. У статті наведено приклади формування навичок успішної професійної мовленнєвої діяльності іноземними мовами в Імператорському Харківському університеті. Визначено, що професійно спрямована медична іноземна мова $\epsilon$ інте- 
грованим предметом, викладання якого поєднує в собі висвітлення питань граматики, лексики, орфографії та пунктуації взагалі класичної іноземної мови, а також вивчення граматики, лексики та стилістики власне медичної іноземної мови. Наголошується, що професійно спрямована медична іноземна мова також тісно пов'язана з предметами медичної та культурологічної спрямованості. Визначено структурні компоненти професійної іншомовної компетентності медика, до яких належать: аксіологічний (мотиви, цілі, цінності), когнітивний (трансформація іншомовних знань різних рівнів у професійній сфері діяльності) і діяльнісний (уміння, форми і способи використання іншомовних знань в професійній діяльності). Зазначено, що діяльнісний компонент професійної іншомовної компетентності медика передбачає реалізацію принципів особистісної і професійної спрямованості, співробітництва, поліфункціональності, проблемного підходу, а також упровадження методів проблемного навчання. Установлено, що упровадження в освітній процес проблемних завдань обумовлює інтерпретацію та актуалізацію фахової інформації на заняттях з іноземної мови, критичне мислення студентів-медиків. Перспективу дослідження автори вбачають у подальшому вивченні та теоретичному аналізі досвіду викладання дисципліни «Іноземна мова (за професійним спрямуванням)» засобом упровадження інноваційних методів та технологій навчання з метою формування іншомовної компетентності майбутніх лікарів.

Ключові слова: професійна культура, лікар, професійна іншомовна компетентність, університет, компоненти професійної іншомовної компетентності медика, студент.

\section{А. В. Овсянникова}

Харьковский национальный медицинский университет проспект науки 4, Харьков, Украина, 61022

Т. В. Лутаева

Харьковский национальный университет имени В. Н. Каразина площадь Свободы4, Харьков, Украина, 61022

\section{ФОРМИРОВАНИЕ ПРОФЕССИОНАЛЬНОЙ КУЛЬТУРЫ БУДУЩИХ ВРАЧЕЙ}

В статье проанализированы особенности формирования профессиональной культуры будущих врачей в образовательном пространстве высших учебных заведений Украины. Констатировано, что составляющей профессиональной культуры врача является коммуникативная культура, что актуализирует необходимость формирования иноязычной компетентности будущих врачей в процессе преподавания дисциплины «Иностранный язык (для профессионального общения)». Авторы акцентируют внимание на существовании традиций межкультурного взаимодействия в образовательном пространстве высшей медицинской школы на Слобожанщине во времена имперской эпохи. В статье приведены примеры формирования навыков успешной профессиональной речевой деятельности на иностранных языках в Императорском Харьковском университете. В работе обосновано, что иностранный язык в высшей медицинской школе является интегрированным предметом. Отмечается, что в современной высшей медицинской школе иностранный язык тесно связан с предметами медицинской и культурологической направленности. Определены структурные компоненты профессиональной иноязычной компетентности медика, к которым относятся: аксиологический (мотивы, цели, ценности), когнитивный (трансформация знаний различных уровней в профессиональной сфере деятельности) и деятельностный (умения, формы и способы использования знаний в профессиональной деятельности). Отмечено, что деятельностный компонент профессиональной иноязычной компетентности медика предполагает реализацию принципов личностной и профессиональной направленности, сотрудничества, полифункциональности, проблемного подхода, а также внедрение методов проблемного обучения. Установлено, что внедрение в образовательный процесс проблемных задач обусловливает интерпретацию и актуализацию профессиональной информации на занятиях по иностранному языку, критическое мышление студентов-медиков. Перспективу исследования авторы видят в дальнейшем изучении и теоретическом анализе опыта преподавания дисциплины «Иностранный язык (для профессионального общения)» средством внедрения инновационных методов и технологий обучения с целью формирования иноязычной компетентности будущих врачей.

Ключевые слова: профессиональная культура, врач, профессиональная иноязычная компетентность, университет, компоненты профессиональной иноязычной компетентности медика, студент.

Introduction. In the present time, the need to strengthen the health care system, improve the quality of medical education, actualizes the problem of the formation of the professional culture of future physicians. The convergence of European higher education systems results in a social order for the training of medical professionals capable of effective, full-fledged, professional foreign communication. The objective need for more active involvement of teachers of foreign languages in the formation of the professional culture of the future physician highlights the need to study the peculiarities of the training of future doctors in the national institutions of higher medical education 
while teaching the discipline «Foreign language (in professional direction)».

Analysis of recent research and publications. Individual scholars (M. Lisovy, R. Grishkov, O. Nalyvayko, O. Lyamova, etc.) analyze the essence, peculiarities of the formation of the professional culture of doctors. The researches of a number of scientists (N. Alekhina, L. Kaidalova, T. Lutaieva, I. Sabatovskaya, etc.) highlight the psychological and pedagogical conditions of formation and development of professional competence and medical professionalism of specialists in the field of health protection. The problem of preparing future specialists for professional foreign language communication was studied by O. Ponomarev, M. Izdylianny, O. Malikhin, S. Melikov, L. Mikhailova and others. Approaches to the training of future physicians in the process of dialogic interaction and problem-based learningare coveredin the works of some researchers (O. Andriychuk, P. Babenko, O. Gumenyuk, K. Kurenkov, T. Korolev, S. Pudov, S. Sarghevsky, L. Sarghevskaya, L. Shkala, O. Yudina, etc.). However, the study of the peculiarities of the training of future doctors in the teaching of foreign languages did not receive adequate coverage in the work of modern scholars.

Objective. The purpose of these materials is to analyze the peculiarities of the formation of the professional culture of future doctors in the educational space of higher education institution.

Methods. To implement the task, we used general scientific and empirical research methods. The historical retrospective method allowed to describe the content and directions of the formation of future doctors' professional culture during the days of the imperial era.

Results. Analysis of research has shown that the concept of «professional culture» is determined by scientists in different ways. Often, professional culture is understood as one of the characteristics of a group of people of the same profession. Some researchers under the professional culture understand the totality of theoretical knowledge and practical skills associated with a particular type of work. According to O. Nalyvayko, the professional culture of a doctor establish the form of the medical culture of humanity that exists within the professional community of medical workers and synthesizes medical knowledge, professional theoretical worldviews, medical technologies and social practices, traditions and the specific language system produced by mankind from the purpose of preserving the health and life of a person, combating its various diseases [5, p.32].

It is noted that traditions of intercultural interaction have developedin the educational space of the Higher Medical School of Slobozhanshchyna. Thus, at the stage of the formation of the national higher medical education (during the days of the imperial era) there was interaction as representatives of the faculty community of the medical faculty of the Imperial Kharkiv University, as well as future medical doctors, with foreign specialists [4]. In particular, at the beginning of the nineteenth century. Graduates of the medical faculty of the Imperial Kharkiv University (hereinafter referred to as the Kharkiv University), for the purpose of career growth, had the opportunity to study at the University of the Professor Institute of the University of Dorpat (1828-1839). It was supposed to have a 3-year study in Dorpat and a 2 - year foreign trip. The language of study at the University of Dorpat was German, expanding the cultural horizons of medical workers of the Russian Empire, created opportunities for establishing creative connections with foreign scholars. Graduates of the medical faculty of Kharkiv University who studied at the Professor's Institute were F. Inozemtsev, O. Filomafitsky [4]. There are reports on the peculiarities of the formation of skills of successful professional speech activity in foreign languages in the educational space of Kharkiv University during the imperial era. It is known that I. Mechnikov, on the initiative of his mentor, Professor of the Department of Physiology of the University, I. Schelkova, published in 1863 in German and Russian, the work «The Study of the Shorth of Warticilles» («Investigations on the Style of Warticelles» - Russian) [3]. It was determined that the search and creative activity of medical students also included the study of special medical literature published in foreign languages. The students' skills with foreign sources [3] were positively evaluated in the reviews of university scientists regarding the scientific work of medical students, which were usually published in the periodical publication «Notes of the Imperial University of Kharkov».

In modern times, according to M. Lisovyi, the indicators of the formation of a communicative culture of a modern physician, as a component of his professional culture, should include: the possession of a culture of constructive dialogue and a polylogue; ability to perceive, reproduce and prepare scientific professional texts; possession of methods of writing and speaking of public speaking; ability to conduct, maintain business conversation. The researcher argues that the speech of the health worker is evidence of his general culture and education [2, c. 5]. It should be noted that the communicative culture of a modern native doctor also implies his foreign competence. 
Expanding the concept of foreign competence of specialists, M. Pradivliannyi connects it with communicative linguistic competencies and notes the presence in this phenomenon of motivational, moral and ethical and other components, aimed at creativity, action, result [6]. It should be noted that the formation of a professional foreign language competence of the future representative of the medical profession depends largely on teaching the discipline «Foreign Language (for professional orientation)». Professionally directed medical foreign language is an integrated subject, teaching combines the coverage of grammar, vocabulary, spelling and punctuation in general with the classical foreign language, as well as the study of grammar, vocabulary and stylistics of a medical foreign language. The discipline is also closely connected with the subjects of medical and cultural orientation. Schematically, the structure of the professional foreign language competence of a future doctor is presented in Figure 1.

The study of psychological and pedagogical literature and the analysis of the personal experience of teaching in a higher school makes it possible to state that the readiness of the teacher of discipline «Foreign Language (in professional direction)» is important in order to motivate learners in mastering a foreign language; updating of the students' personal goals, determined by the need of the society in the representatives of the medical profession, able to solve problems of professional activity at the international level; the formation of values associated with the realities of the globalized world.

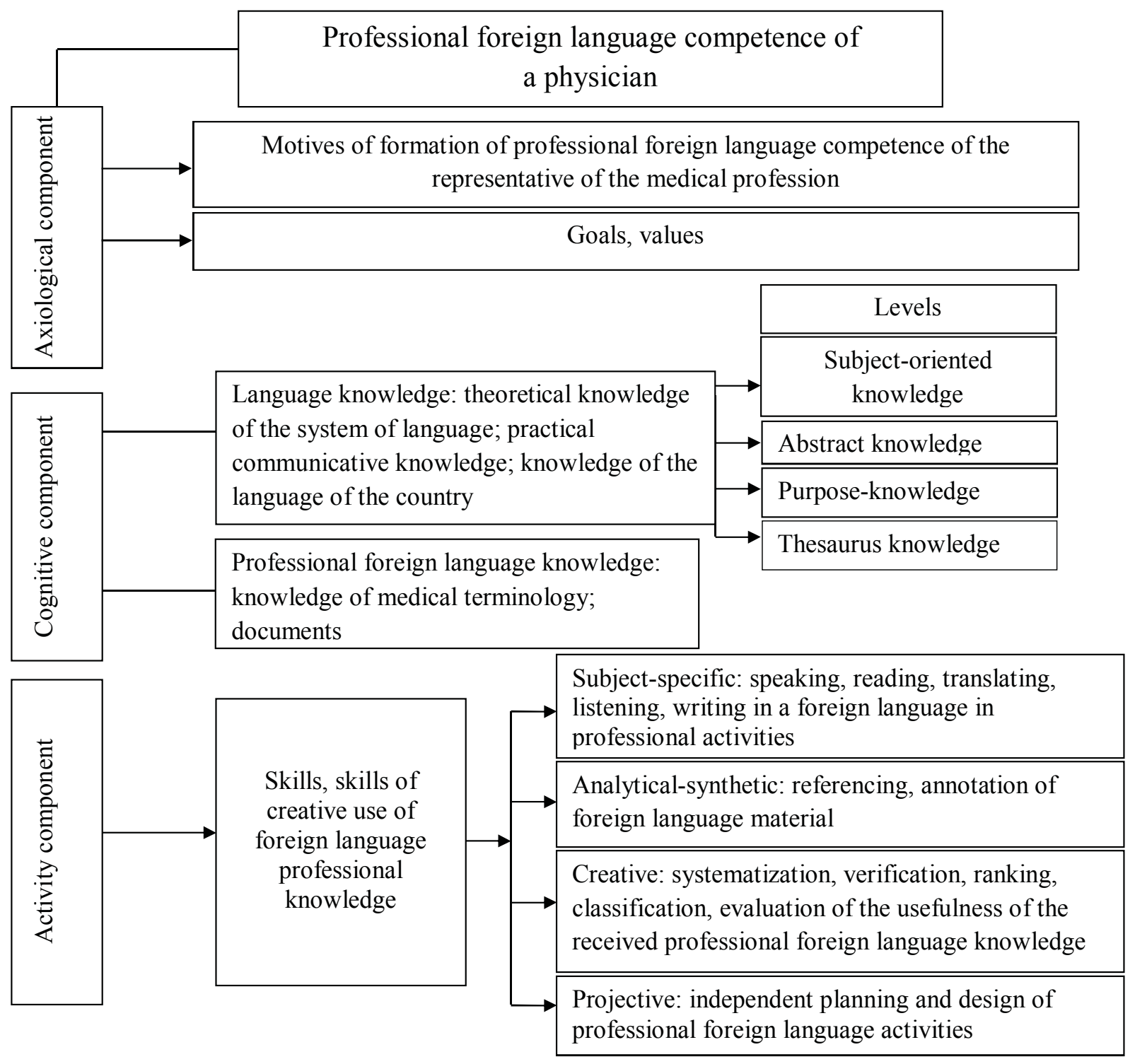

Fig. 1. Structure of professional foreign language competence 
In this case, the teacher should not and can not be the only source of information, but should be able to direct students to search, work independently and know ways to help students learn such information [1].

The cognitive component of the foreign language competence of the future physician reflects the result of the value transformation by the teacher of the discipline «Foreign Language (by professional orientation)» of foreign language knowledge in the field of medical activity in general. It should be said that the accumulation by students of subject-oriented knowledge and their integration at the theoretical, practical, linguistic and ethnographic levels leads to foreign-language knowledge on a qualitatively new level - abstract perception of students of foreign-language material (meta-level), in which foreign language knowledge is characterized by the ability of students to manage knowledge of the previous stages of cognitive accumulation.

It should be noted that besides objectively tentative, abstract and meta-knowledge, the thesaurus level of student's knowledge presupposes the availability of a certain degree of knowledge of a foreign language, as well as information that is necessary to understand certain medical information regarding the development and implementation of a particular communicative act in professional activities.

The active component of the foreign competence of the future physician determines the set of means and methods of activity that the person has learned in the process of achieving the goal. In other words, the activity component reflects the ability of the student's personality to choose a means of action depending on the volume of cognitive foreign-language potential of the individual and the installation of the development of specific foreign language skills.

In nowadays, the researchers update the importance of the latest teaching methods, through which students learn to clearly formulate and express their position, communicate, discuss, perceive and evaluate information, that is, actively use the terms in all activities of a future medical worker.

Students actively, with great desire and interest, participated in the selection of content, methods and means of forming professional foreign language competence based on the principles of personal and professional orientation, cooperation, polyfunctionality, problem approach.

In our opinion,problem tasks is the effective way of forming skills, skills of creative use of for- eign language professional knowledge by medical students. Our experience in teaching the discipline «Foreign Language (by Professional Orientation)» suggests that it is useful to offer students a detailed list of problems for discussion on each topic that is being studied. Since the formation of the student's personality takes place in the activities, it is advisable to offer students a catalog of possible professional situations for discussion in a foreign language from each topic. This is how the future specialists are attracted to direct participation in the formulation of personally significant professional problems, which, in the opinion of students, need discussion.

Problematic situations were used by us in the educational space of the Kharkiv National Medical University (KhNMU). It has been established that their implementation in the educational process is useful not only for group discussion, but also for individual work with students. The attractive force of texts, situations of this type was that there was created a truly natural situation with which students could eventually face both social and professional medical activities. This situation was based on the real needs of students: in self-expression, self-knowledge, self-assertion, self-realization. The problematic situation encouraged students to intensify existing foreign language knowledge, skills, values, search, creative thinking, reflection, logical analysis of the situation - all that is and the structure of professional foreign language competence.

It should be noted that the leading topics in the process of mastering the program on discipline «Foreign Language (for professional orientation)» after inter-subject coordination with programs of professional disciplines have been repeatedly corrected. Teachers of the Department of Foreign Languages of the KhNMU constantly collaborated and exchanged experience with the teachers of medical departments, clarified the basic medical concepts, the possibilities of their learning and use in a foreign language, worked out and coordinated and translated them for students for practical classes. In the process of forming a foreign language competence students were given the opportunity to independently design their own foreign language professional knowledge. To achieve the goal and to overcome the discrepancy between traditional methods, forms of learning and new needs, students were involved in the process of information retrieval and processing, during which there was accumulation, organization and structuring of foreign language knowledge of future professional activities, the essence and ways of forming and self-education of professional 
foreign language competence, the ability of students to systematize and generalize knowledge was revealed.

The principle of personal orientation helped students to fully realize their potential and realize the ability to develop individually. The use of this principle created psychological and pedagogical and organizational conditions for co-creation, the development of individual projects focused on the formation of professional foreign language competence of students, their experience. So, while working on the topic «Medical terminology», namely, before familiarizing students with authentic texts in classes, we have been suggested to discuss the following issues: «Why do you need to read texts?», «What are the reasons for familiarizing with the texts of medical documents by foreigners?» and so on. Students shared their thoughts on the need to read as many authentic texts as possible, the content of which allows you to learn about the features of the medical system, medical problems directly from the speakers of the language. Great interest for students was the theme «My future profession», aimed at mastering them foreign language concepts in relation to the chosen specialty. Particular attention was paid to reading foreign literature on the specialty, whose practical value focused on the sphere of professional interests of the future specialist, and also needed a lot of tension and deep knowledge of students. First of all, this is the knowledge of the speech material (knowledge of vocabulary and grammar), the possession of reading techniques (the ability to read and understand individual words), mastering the technique of understanding the whole text (perception of the text as a whole with its general structural, syntactic and content features). Reading texts in a foreign language implies, besides knowledge of commonly used vocabulary, also the mastery of general scientific and special terminology, which requires a continuous reading practice, which should be started from the first year, as well as the presence of a stable cognitive interest. Therefore, for reading we got texts not only informatively saturated, but also those that represented a professional and cognitive interest for students.
It is necessary to emphasize the importance of organizing work on reading texts in such a way that for students it is possible to show the emotions of satisfaction from the work performed, to succeed on the part of each of them. We have taken into account the fact that the information contained in the text will be personally significant for students only if the content of the text corresponds to their needs and interests, will stimulate their mental activity.

Discussion and conclusions. Thus, the conducted research allows to assert that the component of the professional culture of the doctor is a communicative culture, which involves the formation of foreign competence of future doctors in teaching the discipline «Foreign language (for professional orientation)». The structural components of the professional foreign language competence of the physician are determined, which include: axiological (motives, goals, values), cognitive (transformation of foreign language knowledge of different levels in the professional field of activity) and activity (skills, forms and methods of using foreign language knowledge in professional activity). The active component of the professional foreign language competence of a physician involves the implementation of the principles of personal and professional orientation, cooperation, multifunctionality, problem approach, as well as the introduction of problem-based teaching methods. It has been established that the introduction into the educational process of problem tasks causes the interpretation and updating of professional information in foreign language classes, critical thinking of medical students. We consider the prospect of research in the further study and theoretical analysis of the teaching experience of the discipline «Foreign Language (in professional direction)» as a means of introducing innovative teaching methods and technologies for the purpose of forming the competence of future foreign doctors.

\section{СПИСОК ВИКОРИСТАНИХ ДЖЕРЕЛ ТА ЛІТЕРАТУРИ}

1. Гришкова Р. О. Педагогічні засади формування іншомовної соціокультурної компетенції студентів нефілологічних спеціальностей у процесі фахової підготовки : автореф. докт. дис. 13.00.04. Київ, 2007. $36 \mathrm{c}$.

2. Лісовий М. І. Формування професійного мовлення майбутніх медичних працівників у вищих медичних навчальних закладах : дис. ... канд. пед. наук : спец. 13.00.04. Вінниця, 2006. 196 с.

3. Лутаєва Т. В. Організація самостійної роботи майбутніх медиків та фармацевтів у Харківському університеті (друга пол. XIX - початок XX ст.). Гуманітарний вісник ДВНЗ «Переяслав-Хмельницький державний педагогічний університет імені Григорія Сковороди». Додаток 4 до Вип. 31. Том II (10) : Тематичний випуск «Міжнародні Челпанівські психолого-педагогічні читання». Київ : Гнозис, 2014. С. 254-261. 
2019 Випуск/ Issue 45

4. Лутаєва Т. В. Інтеграція науки і освіти як умова розвитку вищої медико-фармацевтичної школи: історико-педагогічний аспект. Інженерні та освітні технології. Тематичний випуск «Сучасна вища освіта: реалії, проблеми, перспективи. Кременчуг : КрНУ, 2015. № 3 (11). С. 77-79.

5. Наливайко О. Б. Формування професійної культури майбутніх сімейних лікарів у процесі контекстної підготовки : дис. на здобуття наук. ступеня канд. пед. н.: спец. 13.00.04. Вінниця, 2016. 286 с.

6. Прадівлянний М. Г. Компетентнісний підхід при фахово спрямованому викладанні іноземних мов. Наукові записки Тернопільського держ. пед. ун-ту ім. В. Гнатюка. Серія : Педагогіка. Тернопіль, 2006 . № 1. C. $107-110$.

\section{REFERENCES}

1. Hryshkova, R. O. (2007). Pedahohichni zasady formuvannia inshomovnoi sotsiokulturnoi kompetentsii studentiv nefilolohichnykh spetsialnostei u protsesi fakhovoi pidhotovky. [Pedagogical Basics of Forming Socio-cultural Competence in a Foreign Language of Students of Non-philological Specialities in the Process of Professional Training]. (Abstract of candidate's thesis). Kyiv, Ukraine. (in Ukrainian).

2. Lisovyi, M. I. (2006). Formuvannia profesiinoho movlennia maibutnikh medychnykh pratsivnykiv u vyshchykh medychnykh navchalnykh zakladakh [The formation of the professional communication of medical staff in the higher medical educational establishments]. (Candidate's thesis). Vinnytsia, Ukraine. (in Ukrainian).

3. Lutaieva, T. V. (2014). Orhanizatsiia samostiinoi roboty maibutnikh medykiv ta farmatsevtiv u Kharkivskomu universyteti (druha pol. XIX - pochatokXX st.). [Organization of Future Medical and Pharmaceutical Professionals' Independent Work in Kharkov University (second half of 19th - early 20th century)]. Humanitarnyi visnyk DVNZ "Pereiaslav-Khmelnytskyi derzhavnyi pedahohichnyi universytet imeni Hryhoriia Skovorody", 31 (4), II (10): special issue «Mizhnarodni Chelpanivski psykholoho-pedahohichni chytannia». Kyiv, Ukraine, pp. 254-261. (in Ukrainian).

4. Lutaieva, T. V. (2015). Intehratsiia nauky i osvity yak umova rozvytku vyshchoi medyko-farmatsevtychnoi shkoly: istoryko-pedahohichnyi aspekt. [Integration of science and education as a condition of higher medical and pharmaceutical school: historical and pedagogical aspects]. Inzhenerni ta osvitni tekhnolohii. Tematychnyi vypusk «Suchasna vyshcha osvita: realii, problemy, perspektyvy. Kremenchuh, Ukraine. 3 (11), pp. 77-79. (in Ukrainian).

5. Nalyvaiko, O. V. (2016). Formuvannia profesiinoi kultury maibutnikh simeinykh likariv u protsesi kontekstnoi pidhotovky [The future family doctors' professional culture formation in the process of the context preparing]. (Candidate's thesis). Vinnytsia, Ukraine. (in Ukrainian).

6. Pradivliannyi, M. H. (2006). Kompetentnisnyi pidkhid pry fakhovo spriamovanomu vykladanni inozemnykh mov [Competency approach in specialized teaching of foreign languages]. Naukovi zapysky Ternopilskoho derzh. ped. un-tu im. V. Hnatiuka. Seriia : Pedahohika. Ternopil, 1, pp. 107-110. (in Ukrainian). 